\title{
The use of mid-infrared spectrometry to estimate the ration composition of lactating dairy cows
}

\author{
M. Klaffenböck, ${ }^{*}$ A. Steinwidder, ${ }^{1}$ C. Fasching, $\dagger$ G. Terler, $\dagger$ L. Gruber, $\dagger$ G. Mészáros, ${ }^{*}$ and J. Sölkner* \\ *Department of Sustainable Agricultural Systems, University of Natural Resources and Life Sciences Vienna, Division of Livestock Sciences, \\ Gregor-Mendel-Strasse 33, 1180 Vienna, Austria \\ †Federal Agricultural Research and Education Centre Raumberg-Gumpenstein, Altirdning 11, 8952 Irdning-Donnersbachtal, Austria
}

\section{ABSTRACT}

The composition of cow milk is strongly affected by the feeding regimen. Because milk components are routinely determined using mid-infrared (MIR) spectrometry, MIR spectra could also be used to estimate an animal's ration composition. The objective of this study was to determine whether and how well amounts of dry matter intake and the proportions of concentrates, hay, grass silage, maize silage, and pasture in the total ration can be estimated using MIR spectra at an individual animal level. A total of 10,200 milk samples and sets of feed intake data were collected from 90 dairy cows at 2 experimental farms of the Agricultural Research and Education Centre in Raumberg-Gumpenstein, Austria. For each run of analysis, the data set was split into a calibration and a validation data set in a 40:60 ratio. Estimated ration compositions were calculated using a partial least squares regression and then compared with the respective observed ration compositions. In separate analyses, the factors milk yield and concentrate intake were included as additional predictors. To evaluate accuracy, the coefficient of determination $\left(\mathrm{R}^{2}\right)$ and ratio to performance deviation were used. The highest $\mathrm{R}^{2}$ values (for $\mathrm{kg}$ of dry matter intake/ for $\%$ of ration) for the individual feedstuffs were as follows: pasture, $0.63 / 0.66$; grass silage, $0.32 / 0.43$; concentrate intake, 0.39/0.34; maize silage, 0.32/0.33; and hay, 0.15/0.16. Estimation of groups of feedstuffs (forages, energy-dense feedstuffs) mostly resulted in $\mathrm{R}^{2}$ values $>0.50$. Including the parameters milk yield or concentrate intake improved $R^{2}$ values by up to 0.21 , with an average improvement of 0.04 . The results of this study indicate that not all ration components may be estimated equally accurately. Even if some estimates are good on average, there may be strong deviations

\footnotetext{
Received October 21, 2016.

Accepted March 27, 2017.

${ }^{1}$ Corresponding author: Andreas.Steinwidder@raumberg-gump
} enstein.at between estimated and observed values in individual data sets, and therefore individual estimates should not be overemphasized. Further research including pooled samples (e.g., bulk milk, farm samples) or variations in ration composition is called for.

Key words: dairy cow, feed ration, mid-infrared spectrometry, estimation

\section{INTRODUCTION}

Mid-infrared (MIR) spectrometry is currently the method of choice for measuring milk lactose, fat, and protein contents for standard milk recording systems all around the world. In past decades, the MIR spectra of milk samples have been associated with a variety of additional milk- and cow-related parameters, such as the fatty acid profile (Soyeurt et al., 2006; Maurice-Van Eijndhoven et al., 2013; Ferrand-Calmels et al., 2014), major mineral contents (Soyeurt et al., 2009), genetic variability of immune-relevant substances in milk (Soyeurt et al., 2007), methane emissions (Dehareng et al., 2012; Vanlierde et al., 2016), ketone bodies and subclinical ketosis (de Roos et al., 2007; van Knegsel et al., 2010; van Gastelen and Dijkstra, 2016) energy intake (McParland et al., 2015), and body energy balance (McParland et al., 2011). As shown by De Marchi et al. (2014) and Gottardo et al. (2015), MIR spectrometry is an economically viable method for large-scale screening of phenotypes of dairy animals.

The feed ration leaves a "fingerprint" (i.e., patterns in composition) in milk (Sutton, 1989; White et al., 2001; Slots et al., 2009; Larsen et al., 2016), and milk traits such as fatty acid composition have been successfully used to predict ration composition (Coppa et al., 2015). Other milk components that have been explored as potential predictors of diet are carotenoids (Nozière et al., 2006) and UV-absorbing compounds in milk that are related to polyphenols in the feed ration, which are again very specific to the feedstuff (Besle et al., 2010). The MIR spectra of bulk milk samples have also proven useful in distinguishing between feeding systems with 
a high proportion of an individual feedstuff (Valenti et al., 2013). In this study, we assumed that in a similar process the feed ration could be estimated by analyzing the infrared spectrum of individual milk samples. The aim of this study was to examine whether the proportions and absolute amounts of certain feedstuffs and groups of feedstuffs in the rations of lactating dairy cows can be estimated using MIR spectra of individual milk samples.

In this study, we also aimed to provide basic research for the further development of methods for assessing the process quality of milk. These methods may enable the dairy industry to introduce quality programs such as milk from pasture-fed cows or milk produced without silage while avoiding expensive investments in on-farm inspection of production systems. It may be possible to determine the suppliers' average feed rations by using MIR spectra from bulk milk. Another potential application of feed composition estimation via MIR spectra is the examination of discrepancies between offered feed and ingested feed caused by selective feeding behaviors in precision feeding systems. Furthermore, the results might also be considered in breeding value estimation (feeding effects). The infrared spectra of bulk milk are used anyway to quantify major milk components. Thus, methods using MIR spectra provide technical and economic advantages and could support the introduction of specific product lines in the dairy industry.

\section{MATERIALS AND METHODS}

\section{Animals and Materials}

The data in the present study were collected from 7 unpublished studies at the 2 experimental dairy farms (1 organic and 1 conventional) of the Agricultural Research and Education Centre in Raumberg-Gumpenstein, Austria $\left(47^{\circ} 31^{\prime} 03^{\prime \prime} \mathrm{N}, 14^{\circ} 04^{\prime} 26^{\prime \prime} \mathrm{E}\right.$; altitude $=680$ $\mathrm{m}$; average temperature $=7^{\circ} \mathrm{C}$; precipitation $=1,014 \pm$ $63 \mathrm{~mm} / \mathrm{yr})$. The dairy herds comprised cows of 5 contrasting cow breeds or strains: dual-purpose Simmental, Brown Swiss, Holstein Friesian, New Zealand Holstein Friesian, and a specific strain of Holstein Friesian selected for superior lifetime milk yield in an alternative breeding program. A total of 10,200 individual milk samples and feed intake data sets were collected from 90 cows throughout the data recording period from October 8, 2013, to December 12, 2014.

All animals were housed in loose housing systems. Forage ration components were provided 2 times/d after milking, whereas concentrates were fed individually using a concentrate transponder with a maximum amount of $1.5 \mathrm{~kg} /$ visit. The individual forage intake of cows fed in the barn was measured using Calan gates and by recording offered feed and feed refusals at each meal. For all feedstuffs (forages and concentrates), DM was analyzed by drying samples at $105^{\circ} \mathrm{C}$ for $24 \mathrm{~h}$. Depending on the experimental groups, 31 cows were kept on pasture during the grazing season (April until October 2014) for 4 to $21 \mathrm{~h} / \mathrm{d}$. To quantify the feed consumption of these cows, pasture intake was estimated indirectly during the grazing season. Pasture DMI was calculated based on the difference between energy requirement (estimated according to milk yield and milk composition, live weight, live weight change, and pregnancy status) and energy supply from the recorded energy intake in barn (GfE, 2001; Horn et al., 2014). The area of the continuously grazed pasture was adjusted according to sward height, which was targeted to be 3.7 to $5.2 \mathrm{~cm}$ and which was measured once weekly with a rising plate meter. The grazed sward was dominated by perennial ryegrass (Lolium perenne), Kentucky bluegrass (Poa pratensis), and white clover (Trifolium repens). Pasture herbage was sampled as reported by Starz et al. (2010). A precise description of feeding and herd management of cows on pasture can be found in Horn et al. (2013).

All feed samples were pooled over 4 wk and subjected to oven drying for DM determination; proximate analysis (CP, ether extract, crude fiber, ash) according to the guidelines of the Association of German Agricultural Analytic and Research Institutes (VDLUFA, 2007); and analysis of cell wall contents, NDF, and ADF (Van Soest et al., 1991; VDLUFA, 2007) using a Foss Fibertec System (Foss, Hillerød, Denmark). Live weight of all animals was measured once a week after the morning milking. Cows were milked 2 times/d, and daily milk yield was recorded electronically in the entire experimental period. Individual milk samples were prepared by mixing milk samples from morning and evening milkings in equal shares. These samples were collected 3 times/wk (organic farm) or each day (conventional farm), and milk fat, protein, lactose, and urea contents and SCC were determined. The milk samples were preserved using 3 drops of Bronysolv [Bronopol MIT/CIT 3:1 (R38 41-43-52/53; S24 2637/39), ANA. LI.TIK, Vienna, Austria] per $40 \mathrm{~mL}$, as is the standard practice in performance-controlled Austrian dairy farms.

The 10,200 milk samples were sent to an official Austrian milk recording laboratory in St. Michael, Styria, Austria. One infrared spectrum per analyzed milk sample was created using a MilkoScan apparatus (MilkoScan FT6500; Foss). Foss software integrator v1.58 for spectral export determined the results. Measurement of the MIR spectral data and estimation of the milk components were done for every collected sample. The Foss MIR spectrum contained 1,060 data 
points (absorbance rates of infrared light) in the region of 926 to $5,012 \mathrm{~cm}^{-1}$. Pretreatment of all MIR spectra was done according to Rinnan et al. (2009) and Grelet et al. (2016). Spectra of animals that were outliers in a parameter were removed from analysis. Outliers were defined by surpassing a distance of $3 \mathrm{SD}$ to the population mean or not being within the biological optimum of the parameter.

As displayed in Table 1, average lactation number of cows was $1.9 \pm 1.4$ and average ECM yield was 20.2 $\pm 7.0 \mathrm{~kg} / \mathrm{d}$. Milk samples contained $4.3 \pm 0.7 \%$ of fat, $3.3 \pm 0.4 \%$ of protein, and $4.6 \pm 0.2 \%$ of lactose. Cell counts showed high variation, with an average of $153 \pm$ $266 \times 10^{3}$ cells $/ \mathrm{mL}$, and urea content was $20.2 \pm 10.8$ $\mathrm{mg} / 100 \mathrm{~mL}$. Live weight of experimental cows was 545 $\pm 98 \mathrm{~kg}$, and average BCS was $2.8 \pm 0.4$.

The MIR spectrometry estimations were validated for DMI of feedstuffs (in $\mathrm{kg}$ ) and percentages of feedstuffs in the total feed ration (in \%) for 5 individual feedstuffs and 3 groups of feedstuffs. The offered feedstuffs were concentrate $\left(\mathbf{C}_{\mathrm{kg}}, \mathbf{C}_{\%}\right)$, hay $\left(\mathbf{H}_{\mathrm{kg}}, \mathbf{H}_{\%}\right)$, grass silage $\left(\mathbf{G S}_{\mathrm{kg}}, \mathbf{G S}_{\%}\right)$, maize silage $\left(\mathbf{M} \mathbf{S}_{\mathrm{kg}}, \mathbf{M} \mathbf{S}_{\%}\right)$, and pasture $\left(\mathbf{P}_{\mathrm{kg}}, \mathbf{P}_{\mathbf{\%}}\right)$. The first group consisted of hay and grass silage and was named forages $\mathrm{A}\left(\mathbf{F A}_{\mathrm{kg}}\right.$, $\left.\mathbf{F A}_{\%}\right)$. The second group included hay, grass silage, and pasture and was named forages $\mathrm{B}\left(\mathbf{F B}_{\mathrm{kg}}, \mathbf{F} \mathbf{B}_{\%}\right)$. The third group comprised all energy-dense feedstuffs, specifically concentrate and maize silage $\left(\mathbf{E D F}_{\mathbf{k g}}, \mathbf{E D F}_{\%}\right)$. In Austria, FA (hay and grass silage) is the most common dietary basis for dairy farms, especially in winter; FB (hay, grass silage, and pasture) is the dietary basis for farms that use pasture to a greater extent, which is a feeding system worth authenticating in our opinion. Concentrates and maize silage (full plant silage, including the starchy cobs and seeds) were grouped together as EDF because the way it is used maize silage can be considered more a concentrate feedstuff than a forage.

The average DMI of the experimental cows was 15.1 $\pm 4.2 \mathrm{~kg}$ of DM, comprising $11.3 \pm 3.8 \mathrm{~kg}$ of DM forages, $3.3 \pm 3.0 \mathrm{~kg}$ of DM concentrate, and $2.6 \pm 1.7$ $\mathrm{kg}$ of DM maize silage (Table 2). The proportion of FA (hay and grass silage) in total feed intake was $47.4 \pm$ $25.0 \%$, with an average intake of $3.2 \pm 3.1 \mathrm{~kg}$ of DM hay and $4.4 \pm 3.2 \mathrm{~kg}$ of DM grass silage. The FB group (hay, grass silage, and pasture) includes the estimated $2.1 \pm 4.6 \mathrm{~kg}$ of DMI from pasture and results in 63.3 $\pm 20.0 \%$ of the total feed intake. The EDF adds up to $5.8 \pm 4.0 \mathrm{~kg}$ and $36.7 \pm 20.0 \%$. Energy concentrations per kilogram of $\mathrm{DM}$ were $8.47 \pm 0.12 \mathrm{MJ}$ of $\mathrm{NE}_{\mathrm{L}}$ for concentrates, $5.88 \pm 0.15 \mathrm{MJ}$ of $\mathrm{NE}_{\mathrm{L}}$ for hay, $5.98 \pm$ $0.10 \mathrm{MJ}$ of $\mathrm{NE}_{\mathrm{L}}$ for grass silage, $6.33 \pm 0.08 \mathrm{MJ}$ of $\mathrm{NE}_{\mathrm{L}}$ for maize silage, and $6.40 \pm 0.22 \mathrm{MJ}$ of $\mathrm{NE}_{\mathrm{L}}$ for pasture.

As animals in this study were kept on different farms and under different dietary regimens, the composi-
Table 1. Cow- and milk-related data (SD in parentheses) from 10,200 records from 90 cows

\begin{tabular}{lccc}
\hline Parameter & Mean & Minimum & Maximum \\
\hline Lactation number & $1.9(1.4)$ & 1 & 9 \\
Milk yield (kg/d) & $20.0(7.0)$ & 5.0 & 47.7 \\
ECM (kg/d) & $20.2(7.0)$ & 1.8 & 52.8 \\
Milk fat (\%) & $4.3(0.7)$ & 2.7 & 6.4 \\
Milk protein (\%) & $3.2(0.4)$ & 2.2 & 4.3 \\
Milk lactose (\%) & $4.6(0.2)$ & 4.0 & 5.2 \\
Milk fat (kg) & $0.84(0.32)$ & 0.07 & 1.80 \\
Milk protein $(\mathrm{kg})$ & $0.65(0.24)$ & 0.06 & 1.37 \\
Cells (1,000/mL) & $153(266)$ & 6 & 1,000 \\
Urea (mg/100 mL) & $20.2(10.8)$ & 5.0 & 60.0 \\
Live weight $(\mathrm{kg})$ & $545(98)$ & 301 & 992 \\
BCS & $2.8(0.4)$ & 1.8 & 4.1 \\
Back fat $(\mathrm{mm})$ & $13.7(7.8)$ & 7.0 & 40.1 \\
\hline
\end{tabular}

tion of the concentrate blends offered varied between animals. As shown in Table 3, the average concentrate mixture used this study comprised $1.26 \pm 1.11 \mathrm{~kg}$ of barley, $0.55 \pm 0.61 \mathrm{~kg}$ of corn, $0.39 \pm 0.36 \mathrm{~kg}$ of soybean meal, $0.39 \pm 0.37 \mathrm{~kg}$ of rapeseed meal, $0.64 \pm$ $1.21 \mathrm{~kg}$ of wheat, and smaller amounts $(<0.25 \mathrm{~kg}$ each $)$ of dried sugar beet pulp, soybean hulls, peas, triticale, oats, and wheat bran. Data in Tables 1, 2, and 3 are presented for the whole test population instead of for animals from calibration and validation data sets separately because calibration and validation data sets were randomly reassorted for every run of the procedure. We assume that means of the presented data were evened out over 400 runs of the procedure.

\section{Statistical Analysis}

Software used in this study was SAS 9.4 TS Level 1M2 (SAS Institute, Cary, NC) for statistical analysis and Microsoft Excel (version 14.0.7165.5000; Microsoft, Redmond, WA) for descriptive statistics. In this study, a partial least squares (PLS) regression model was used. The MIR spectrometry estimations of DMI (in $\mathrm{kg}$ ) and proportion of feedstuffs in the total feed ration (in \%) were cross-validated and validated for 5 feedstuffs and 3 groups of feedstuffs. Thus, the data set of 10,200 samples was divided into a calibration data set and a validation data set for each run of the PLS procedure. Measures were taken to ensure that all samples of an individual animal were exclusively in 1 of the data sets for each run. Based on preliminary analyses, a 40:60 ratio for calibration:validation data sets was chosen. These percentages delivered the highest average correlations between true and estimated values while still ensuring reasonable computing times. The composition of these categories of samples was completely randomized according to these proportions for each of 50 runs. All results obtained by the PLS 
Table 2. Observed data (SD in parentheses) on feed intake [in $\mathrm{kg}$ of $\mathrm{DM}$ (subscript $\mathrm{kg}$ ) or proportion (subscript \%)] of experimental animals

\begin{tabular}{|c|c|c|c|c|}
\hline \multirow[b]{2}{*}{ Feedstuff $^{1}$} & \multicolumn{3}{|c|}{ Intake ( $\mathrm{kg}$ of $\mathrm{DM}$ or $\%)$} & \multirow{2}{*}{$\begin{array}{l}\text { Mean energy content } \\
\text { (MJ of } \mathrm{NE}_{\mathrm{L}} / \mathrm{kg} \text { of } \mathrm{DM} \text { ) }\end{array}$} \\
\hline & Mean & Minimum & Maximum & \\
\hline All feed & $15.1(4.2)$ & 5.0 & 27.0 & $6.57(0.36)$ \\
\hline $\mathrm{C}_{\mathrm{kg}}$ & $3.3(3.0)$ & 0.0 & 13.5 & $8.47(0.12)$ \\
\hline $\mathrm{H}_{\mathrm{kg}}$ & $3.2(3.1)$ & 0.0 & 23.0 & $5.88(0.15)$ \\
\hline $\mathrm{GS}_{\mathrm{kg}}$ & $4.4(3.2)$ & 0.0 & 22.6 & $5.98(0.10)$ \\
\hline $\mathrm{MS}_{\mathrm{kg}}$ & $2.6(1.7)$ & 0.0 & 7.4 & $6.33(0.08)$ \\
\hline $\mathrm{P}_{\mathrm{kg}}{ }^{2 \mathrm{~g}}$ & $2.1(4.6)$ & 0.0 & 21.4 & $6.40(0.22)$ \\
\hline $\mathrm{FA}_{\mathrm{kg}}$ & $7.3(4.4)$ & 0.0 & 23.0 & $5.94(0.10)$ \\
\hline $\mathrm{FB}_{\mathrm{kg}}$ & $9.3(3.4)$ & 1.6 & 23.0 & $6.00(0.17)$ \\
\hline $\mathrm{EDF}_{\mathrm{kg}}$ & $5.8(4.0)$ & 0.0 & 17.9 & $7.56(0.66)$ \\
\hline $\mathrm{C}_{\%}$ & $19.9(15.0)$ & 0.0 & 65.2 & \\
\hline $\mathrm{H}_{\%}$ & $19.4(16.0)$ & 0.0 & 100.0 & \\
\hline $\mathrm{GS}_{\%}$ & $28.1(19.0)$ & 0.0 & 100.0 & \\
\hline $\mathrm{MS}_{\%}$ & $16.8(11.0)$ & 0.0 & 39.5 & \\
\hline $\mathrm{P}_{\%}{ }^{20}$ & $15.8(35.0)$ & 0.0 & 100.0 & \\
\hline $\mathrm{FA}_{\%}$ & $47.4(25.0)$ & 0.0 & 100.0 & \\
\hline $\mathrm{FB}_{\%}$ & $63.3(20.0)$ & 20.1 & 100.0 & \\
\hline $\mathrm{EDF}_{\%}$ & $36.7(20.0)$ & 0.0 & 79.9 & \\
\hline
\end{tabular}

procedure that are presented in this study are means of these 50 runs conducted for each feedstuff or group of feedstuffs. The PLS procedure creates a prediction equation by extracting latent variables $(\mathbf{L V})$ - a set of explanatory components with the most estimative power. The procedure for choosing the adequate number of LV for each category was adapted from Prinz (2015) and McParland et al. (2011). In these articles, runs with different numbers of $\mathrm{LV}$ were tested and the results were compared. Too few variables would oversimplify the model, and too many variables would overparameterize it; both would lead to a suboptimal coefficient of determination in the validation data set $\left(\mathbf{R}_{\text {val }}^{2}\right.$; McParland et al., 2011). When the increase in $L V$ no longer resulted in a significant increase in $R_{\text {val }}^{2}$, the number of LV was set at 40. Two indicators of ac-

Table 3. Feed components (SD in parentheses) in the concentrates

\begin{tabular}{lcc}
\hline Component & $\begin{array}{c}\text { Mean intake } \\
(\mathrm{kg} \text { of DM) }\end{array}$ & $\begin{array}{c}\text { Mean proportion } \\
(\%)\end{array}$ \\
\hline Barley & $1.26(1.11)$ & $32.7(7.9)$ \\
Corn & $0.55(0.61)$ & $19.6(11.6)$ \\
Soybean meal & $0.39(0.36)$ & $10.4(4.0)$ \\
Rapeseed meal & $0.39(0.37)$ & $10.4(4.0)$ \\
Wheat & $0.64(1.21)$ & $10.1(16.2)$ \\
Dried sugar beet pulp & $0.22(0.28)$ & $8.2(6.5)$ \\
Soybean hulls & $0.14(0.21)$ & $5.5(5.6)$ \\
Pea & $0.05(0.22)$ & $1.4(5.0)$ \\
Triticale & $0.02(0.16)$ & $1.1(5.9)$ \\
Oats & $0.01(0.05)$ & $0.3(1.3)$ \\
Wheat bran & $0.01(0.05)$ & $0.2(1.0)$ \\
\hline
\end{tabular}

curacy of the estimates were used: (1) the $\mathrm{R}_{\text {val, }}^{2}$, and (2) the ratio to performance deviation (RPD), calculated by dividing the standard deviation of the mean of the observed values by the mean root-mean-squared error (RMSE) of the respective feedstuff.

To potentially improve the correlation between observed and estimated values, more factors were added to the PLS procedure apart from the absorption rates of the MIR spectra. Factors were selected for their potential availability to dairy processing plants, which might benefit from a method for estimating intake of certain feedstuffs in the future, as well as their potential to improve correlation coefficient in test runs. The procedure was supplemented with information on milk yield, amount of concentrate fed, and the combination of both to examine whether information about these factors would improve indicators of accuracy of the estimates. The results of the original analysis considering only MIR spectra in the set of explanatory variables are displayed as variant 1 , and the runs with additional explanatory variables are displayed as variants 2 through 4.

To display the average deviation of the estimated values from the mean of observed values, the RMSE was calculated. Because this value holds the same unit as the estimated values ( $\mathrm{kg}$ or \%) and depends on the average of observed values for interpretation, further parameters were included. To quantify systematic errors in estimation, mean bias of estimation and slope between true and predicted values were calculated. 
Table 4. Statistics (SD in parentheses) for the calibration equations (in calibration and validation data sets) developed for the prediction of feed ration of lactating dairy cows with no additional factors included in the partial least squares procedure (variant 1$)^{1}$

\begin{tabular}{|c|c|c|c|c|c|c|c|}
\hline Feedstuff $^{2}$ & \multicolumn{2}{|c|}{ Calibration } & \multicolumn{5}{|c|}{ Validation } \\
\hline $\mathrm{GS}_{\mathrm{kg}}$ & 2.27 & $0.48(0.07)$ & 2.55 & $-0.07(0.32)$ & $0.90(0.18)$ & $0.32(0.06)$ & 1.26 \\
\hline $\mathrm{MS}_{\mathrm{kg}}$ & 1.19 & $0.53(0.05)$ & 1.42 & $0.06(0.24)$ & $0.83(0.15)$ & $0.32(0.07)$ & 1.21 \\
\hline$P_{k g}^{k g}$ & 2.38 & $0.69(0.05)$ & 2.80 & $0.05(0.48)$ & $1.02(0.15)$ & $0.63(0.04)$ & 1.66 \\
\hline $\mathrm{EDF}_{\mathrm{kg}}$ & 2.26 & $0.66(0.07)$ & 2.68 & $-0.07(0.46)$ & $0.97(0.11)$ & $0.54(0.04)$ & 1.48 \\
\hline $\mathrm{C}_{\%}$ & 10.21 & $0.58(0.04)$ & 12.65 & $-0.25(2.45)$ & $0.86(0.14)$ & $0.34(0.08)$ & 1.21 \\
\hline $\mathrm{H}_{\%}$ & 12.77 & $0.35(0.06)$ & 14.40 & $-0.61(1.90)$ & $0.66(0.29)$ & $0.16(0.06)$ & 1.10 \\
\hline $\mathrm{GS}_{\%}$ & 12.24 & $0.57(0.05)$ & 13.99 & $-0.46(1.94)$ & $0.92(0.13)$ & $0.43(0.06)$ & 1.35 \\
\hline $\mathrm{MS}_{\%}$ & 7.70 & $0.56(0.04)$ & 9.35 & $0.07(1.68)$ & $0.84(0.18)$ & $0.33(0.09)$ & 1.20 \\
\hline $\mathrm{P}_{\%}$ & 17.17 & $0.76(0.02)$ & 20.37 & $0.54(3.33)$ & $1.03(0.13)$ & $0.66(0.04)$ & 1.71 \\
\hline $\mathrm{FA}_{\%}$ & 14.12 & $0.67(0.02)$ & 16.85 & $-0.76(2.87)$ & $0.97(0.15)$ & $0.54(0.08)$ & 1.47 \\
\hline
\end{tabular}

${ }^{1} \mathrm{RMSE}=$ root mean squared error; RPD = ratio to performance deviation (SD/RMSE).

${ }^{2} \mathrm{C}=$ concentrate; $\mathrm{H}=$ hay; $\mathrm{GS}=$ grass silage; $\mathrm{MS}=$ maize silage; $\mathrm{P}=$ pasture; $\mathrm{FA}=$ forages $\mathrm{A}$ (consisted of hay and grass silage) $\mathrm{FB}=$ forages $\mathrm{B}$ (consisted of hay, grass silage, and pasture); EDF = energy-dense feedstuffs (specifically concentrate and maize silage). Subscript kg $=$ kilograms of DMI in feedstuffs; subscript $\%=$ percentages of feedstuffs in the total feed ration.

Bias was considered to be not significant (at $P=0.05$ ) if absolute value of bias $-\mathrm{SD} \times 1.96<0$. Slope was considered to be not significantly different from 1 if magnitude $(1-$ slope $)-\mathrm{SD} \times 1.96>0$.

\section{RESULTS AND DISCUSSION}

The results of the PLS procedure without any additional explanatory factors (variant 1) and various statistical parameters are displayed in Table 4 . The $\mathrm{R}_{\text {val }}^{2}$ ranged from 0.15 in $\mathrm{H}_{\mathrm{kg}}$ to 0.66 in $\mathrm{P}_{\%}$. Other categories with $\mathrm{R}_{\text {val }}^{2}$ of 0.50 or higher were $\mathrm{P}_{\mathrm{kg}}, \mathrm{FA}_{\mathrm{kg}}, \mathrm{FB}_{\%}, \mathrm{EDF}_{\mathrm{kg}}$, $\mathrm{EDF}_{\%}, \mathrm{P}_{\%}, \mathrm{FA}_{\%}$, and $\mathrm{FB}_{\%}$. The $\mathrm{R}_{\text {val }}^{2}$ was below 0.50 in all other categories. Bias was not significant and slope was not significantly different from 1 in all categories. The RPD values ranged from 1.09 for $\mathrm{H}_{\mathrm{kg}}$ to 1.71 for $\mathrm{P}_{\%}$.

Table 5 displays the results of the PLS procedure accomplished by adding the factor milk yield at each particular testing day (variant 2). Several feedstuffs showed $\mathrm{R}_{\text {val }}^{2}$ of 0.6 or higher in this variant: $\mathrm{C}_{\mathrm{kg}}(0.60)$, $\mathrm{P}_{\mathrm{kg}}(0.63), \mathrm{EDF}_{\mathrm{kg}}(0.67) \mathrm{P}_{\%}(0.68), \mathrm{FB}_{\%}(0.60)$, and $\mathrm{EDF}_{\%}(0.60)$. Bias was not significant and slope was not significantly different from 1 in all categories. The RPD values ranged from 1.10 in $\mathrm{H}_{\mathrm{kg}}$ to 1.75 in $\mathrm{P}_{\%}$.

In variant 3 of the PLS procedure, the factor concentrate intake was added in the same manner that milk yield was added in variant 2 . In this case, analyses were not performed for prediction of concentrates and EDF. The results are shown in Table 6 . The highest $\mathrm{R}_{\text {val }}^{2}$ values were found for $\mathrm{FB}_{\%}(0.76)$ and for $\mathrm{P}_{\mathrm{kg}}$ and

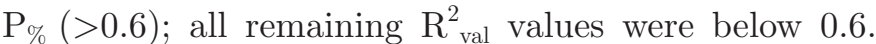
Bias was not significant and slope was not significantly different from 1 in all categories. For RPD, $\mathrm{FB}_{\%}$ surpassed the threshold of 2.00 with 2.04 , and $\mathrm{P}_{\mathrm{kg}}, \mathrm{P}_{\%}$, and $\mathrm{FA}_{\%}$ reached values between 1.50 and 2.00.

The results of variant 4 of the PLS procedure, in which the factors milk yield and concentrate were added both, are shown in Table 7 . The highest $\mathrm{R}_{\text {val }}^{2}$ occurred in $\mathrm{FB}_{\%}(0.76) ; \mathrm{P}_{\mathrm{kg}}$ and $\mathrm{P}_{\%}$ also showed $\mathrm{R}_{\mathrm{val}}$ values above 0.60 . Bias was not significant and slope was not significantly different from 1 in all categories. For RPD, only $\mathrm{FB}_{\%}$ surpassed the threshold of 2.00 with 2.03, and $\mathrm{P}_{\mathrm{kg}}, \mathrm{FA}_{\mathrm{kg}}, \mathrm{P}_{\%}$, and $\mathrm{FA}_{\%}$ reached values between 1.50 and 2.00 .

Determining thresholds above and below which the correlation coefficient and RPD should be to be considered accurate was difficult because most comparable studies have examined certain substances in milk, such as mineral content (Soyeurt et al., 2009) or fatty acid composition (Soyeurt et al., 2006). The indirect nature of this research needs to be considered in evaluating the degree of accuracy of prediction. In contrast to research investigating actual components in milk samples, we looked for a "fingerprint" of the feed ration in the MIR spectrum of the milk in this study, which might be caused by a variety of milk components depending on which feedstuff is considered. Thus, we expected a comparatively lower accuracy of estimates for quantities and percentages of feedstuffs. Coppa et al. (2015) used fatty acid profiles from bulk milk samples to predict ration proportions of feedstuffs and yielded a higher 
Table 5. Statistics (SD in parentheses) for the calibration equations (in calibration and validation data sets) developed for the estimation of feed ration of lactating dairy cows with milk yield included as an additional factor in the partial least squares procedure (variant 2$)^{1}$

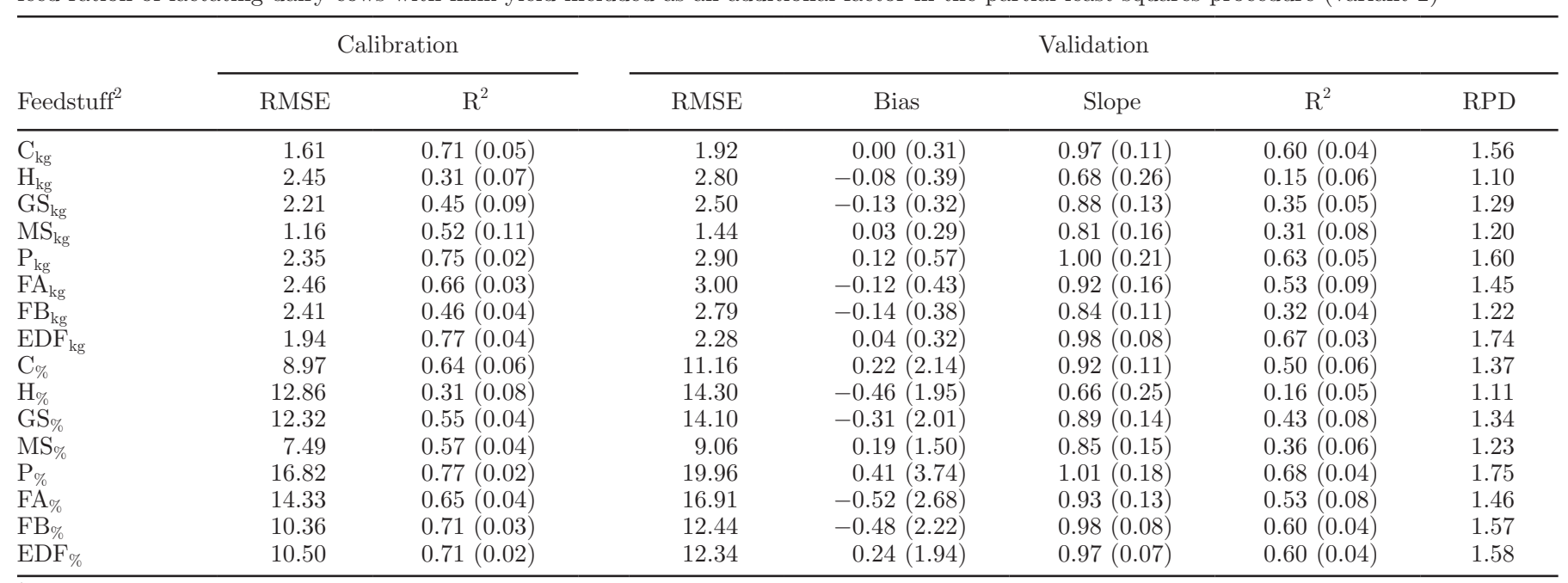

${ }^{1} \mathrm{RMSE}=$ root mean squared error; $\mathrm{RPD}=$ ratio to performance deviation (SD/RMSE).

${ }^{2} \mathrm{C}=$ concentrate; $\mathrm{H}=$ hay; $\mathrm{GS}=$ grass silage; $\mathrm{MS}=$ maize silage; $\mathrm{P}=$ pasture; $\mathrm{FA}=$ forages $\mathrm{A}$ (consisted of hay and grass silage); $\mathrm{FB}=$ forages $\mathrm{B}$ (consisted of hay, grass silage, and pasture); $\mathrm{EDF}=$ energy-dense feedstuffs (specifically concentrate and maize silage). Subscript $\mathrm{kg}=$ kilograms of DMI in feedstuffs; subscript \% = percentages of feedstuffs in the total feed ration.

$\mathrm{R}_{\text {val }}^{2}$ (e.g., 0.81 for fresh herbage compared with 0.63 for pasture in this study).

Target values for the correlation $\mathrm{R}_{\text {val }}^{2}$ defined in other publications using MIR spectrometry are, for example, $>0.75$ for animal breeding and $>0.95$ for incorporation in milk payment systems (Soyeurt et al., 2011) or 0.66 $\leq \mathrm{R}_{\text {val }}^{2} \leq 0.81$ for approximate quantitative predictions, $0.82 \leq \mathrm{R}_{\text {val }}^{2} \leq 0.90$ for good predictions, and $\mathrm{R}_{\text {val }}^{2}>$ 0.91 for excellent predictions (Karoui et al., 2006). For the RPD, Karoui et al. (2006) considered values $>10$ to be equivalent to the reference method, values $>2$ to be adequate for analytical purposes, and values $<1.5$ to be indicative of incorrect estimates. For interpretation of $\mathrm{R}^{2}$ values in this publication, we referred to more comparable studies such as those concerning the prediction of body energy status in dairy cows using MIR spectrometry by McParland et al. (2011, 2012), which consider estimations with $\mathrm{R}_{\text {val }}^{2}$ of between 0.25 and 0.64 to be reasonably accurate. Vanlierde et al. (2016) achieved an $\mathrm{R}_{\text {val }}^{2}$ of 0.70 in their prediction of methane emissions from MIR spectra and described the resulting equation as sufficient for widespread screening in dairy herds and useful for the development of management and selection strategies.

Table 6. Statistics (SD in parentheses) for the calibration equations (in calibration and validation data sets) developed for the prediction of feed ration of lactating dairy cows with concentrate included as an additional factor in the partial least squares procedure (variant 3$)^{1}$

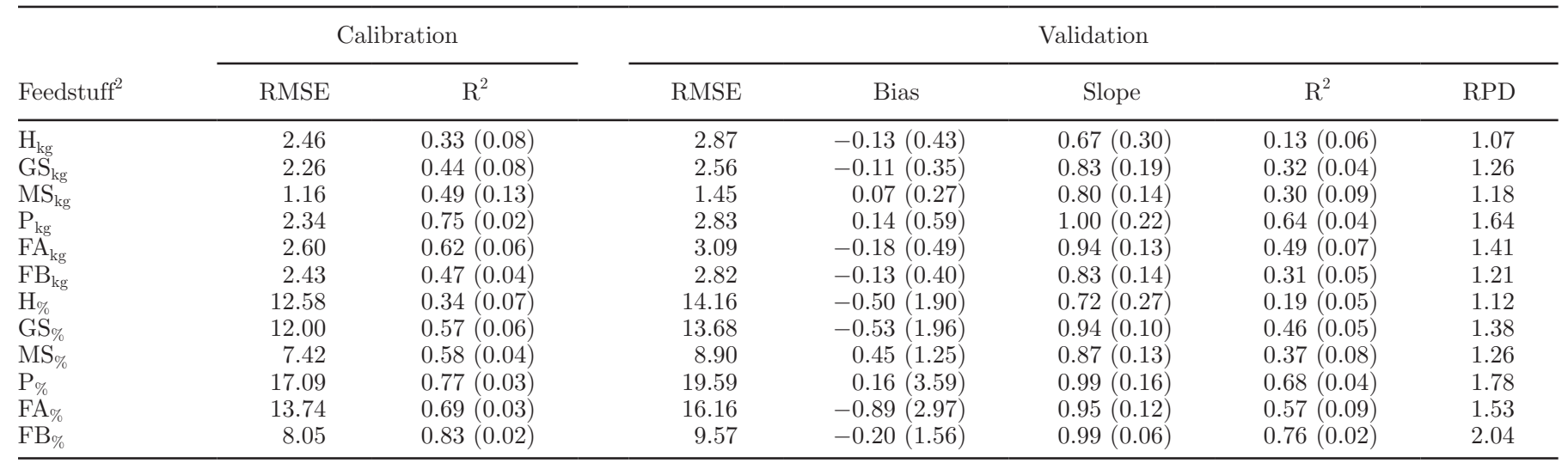

${ }^{1} \mathrm{RMSE}=$ root mean squared error; $\mathrm{RPD}=$ ratio to performance deviation (SD/RMSE).

${ }^{2} \mathrm{H}=$ hay; GS = grass silage; $\mathrm{MS}=$ maize silage; $\mathrm{P}=$ pasture; $\mathrm{FA}=$ forages $\mathrm{A}$ (consisted of hay and grass silage); FB = forages $\mathrm{B}$ (consisted of hay, grass silage, and pasture). Subscript $\mathrm{kg}=$ kilograms of DMI in feedstuffs; subscript $\%=$ percentages of feedstuffs in the total feed ration. 
Table 7. Statistics (SD in parentheses) for the calibration equations (in calibration and validation data sets) developed for the prediction of feed ration of lactating dairy cows with milk yield and concentrate included as additional factors in the partial least squares procedure (variant 4$)^{1}$

\begin{tabular}{|c|c|c|c|c|c|c|c|}
\hline \multirow[b]{2}{*}{ Feedstuff $^{2}$} & \multicolumn{2}{|c|}{ Calibration } & \multicolumn{5}{|c|}{ Validation } \\
\hline & RMSE & $\mathrm{R}^{2}$ & RMSE & Bias & Slope & $\mathrm{R}^{2}$ & $\mathrm{RPD}$ \\
\hline $\mathrm{GS}_{\mathrm{kg}}$ & 2.21 & $0.50(0.09)$ & 2.49 & $-0.04(0.28)$ & $0.87(0.12)$ & $0.35(0.05)$ & 1.29 \\
\hline $\mathrm{MS}_{\mathrm{kg}}^{\mathrm{Kg}}$ & 1.15 & $0.52(0.11)$ & 1.42 & $0.08(0.22)$ & $0.81(0.14)$ & $0.32(0.06)$ & 1.21 \\
\hline $\mathrm{P}_{\mathrm{kg}}$ & 2.34 & $0.75(0.03)$ & 2.81 & $0.09(0.48)$ & $1.01(0.17)$ & $0.64(0.04)$ & 1.65 \\
\hline $\mathrm{FA}_{\mathrm{kg}}$ & 2.44 & $0.68(0.04)$ & 2.87 & $-0.21(0.42)$ & $0.94(0.13)$ & $0.56(0.07)$ & 1.52 \\
\hline $\mathrm{GS}_{\%}$ & 11.87 & $0.56(0.08)$ & 13.92 & $-0.88(1.89)$ & $0.93(0.12)$ & $0.45(0.06)$ & 1.36 \\
\hline $\mathrm{MS}_{\%}$ & 7.25 & $0.54(0.05)$ & 9.05 & $0.33(1.52)$ & $0.84(0.14)$ & $0.36(0.07)$ & 1.24 \\
\hline $\mathrm{P}_{\%}$ & 16.82 & $0.78(0.02)$ & 19.66 & $0.51(3.49)$ & $0.99(0.15)$ & $0.68(0.03)$ & 1.77 \\
\hline $\mathrm{FA}_{\%}$ & 13.25 & $0.70(0.02)$ & 16.35 & $-1.29(3.07)$ & $0.94(0.12)$ & $0.57(0.09)$ & 1.51 \\
\hline $\mathrm{FB}_{\%}$ & 7.98 & $0.84(0.02)$ & 9.64 & $-0.09(1.68)$ & $0.99(0.06)$ & $0.76(0.03)$ & 2.03 \\
\hline
\end{tabular}

${ }^{1} \mathrm{RMSE}=$ root mean squared error; $\mathrm{RPD}=$ ratio to performance deviation (SD/RMSE).

${ }^{2} \mathrm{H}=$ hay; $\mathrm{GS}=$ grass silage; $\mathrm{MS}=$ maize silage; $\mathrm{P}=$ pasture; $\mathrm{FA}=$ forages $\mathrm{A}$ (consisted of hay and grass silage); $\mathrm{FB}=$ forages $\mathrm{B}$ (consisted of hay, grass silage, and pasture). Subscript $\mathrm{kg}=$ kilograms of DMI in feedstuffs; subscript $\%=$ percentages of feedstuffs in the total feed ration.

The $\mathrm{R}_{\text {val }}^{2}$ for several individual feedstuffs (grass silage, maize silage, and concentrate) ranged between 0.32 and 0.43 ; RPD values ranged between 1.20 and 1.35. Prediction of hay feeding reached relatively low values for $\mathrm{R}_{\text {val }}^{2}\left(\mathrm{H}_{\mathrm{kg}}=0.15\right.$ and $\left.\mathrm{H}_{\%}=0.16\right)$ and $\mathrm{RPD}$ (1.09 and 1.10), whereas pasture showed relatively high $\mathrm{R}_{\text {val values }}^{2}\left(\mathrm{P}_{\mathrm{kg}}=0.63 ; \mathrm{P}_{\%}=0.66\right)$ and $\mathrm{RPD}$ values $\left(\mathrm{P}_{\mathrm{kg}}=1.66 ; \mathrm{P}_{\%}=1.71\right)$. The relatively good accuracy of estimation for pasture intake corresponds with studies reporting that pasture has a considerable effect on milk composition, in particular on the fatty acid composition and milk urea content (White et al., 2001; Slots et al., 2009; Stergiadis et al., 2015). However, including other feedstuffs with a similar effect on milk fatty acids (e.g., fresh-cut forage offered in barn) may distort estimations of pasture intake. Furthermore, the predictive potential of MIR spectra seemed to be greater for groups of feedstuffs than for single feedstuffs.

The effect of adding additional predictor variables to the model on estimation accuracy is shown in Table 8 . When we added milk yield as an additional predictor (variant 2), the highest improvements relative to $\mathrm{R}_{\text {val }}^{2}$ in variant $1\left(\mathbf{I}_{\mathbf{R}}{ }^{2}\right)$ were 0.21 for $\mathrm{C}_{\mathrm{kg}}, 0.13$ for $\mathrm{EDF}_{\mathrm{kg}}$, and 0.16 for $\mathrm{C}_{\%}$. Superior results $(P<0.01)$ were also achieved in $\mathrm{FB}_{\%}(0.05)$ and $\mathrm{EDF}_{\mathrm{kg}}(0.06)$. We assume that the increase in accuracy for concentrate and EDF originates from the close positive correlation of intake of high-energy feedstuffs and milk yield.

Including concentrate intake as a predictor (variant 3) caused strong improvement of accuracy for $\mathrm{FB}_{\%}$, with an $\mathrm{I}_{\mathrm{R}}{ }^{2}$ of 0.21 and an $\mathrm{R}_{\text {val }}^{2}$ of 0.76 . Because $\mathrm{FB}$ comprises hay, grass silage, and pasture, adding concentrate intake as a predictor leads to a model that contains information on almost all feedstuffs (excluding only maize silage). Thus, if concentrate intake is known, forage intake can be estimated with very high accuracy. Other $\mathrm{I}_{\mathrm{R}}{ }^{2}$ values of 0.03 or higher in variant 3 were observed for $\mathrm{MS}_{\%}$ and $\mathrm{H}_{\%}$; all other values were smaller. Variant 4 , which includes both milk yield and concentrate intake as predictors, produced higher $\mathrm{R}_{\text {val }}^{2}$ and lower RPD values for almost all feedstuffs and groups of feedstuffs considered. The $\mathrm{I}_{\mathrm{R}}{ }^{2}$ was generally between 0.00 and 0.06 , with the exception of 0.11 for $\mathrm{FB}_{\mathrm{kg}}$ and 0.21 for $\mathrm{FB}_{\%}$.

Table 9 shows the average estimated values (in $\mathrm{kg}$ or \%) for a feedstuff when the observed value for the respective sample was 0 ; that is, no amount of the feedstuff was fed. These estimations seemed to be biased compared with the accuracy of prediction over all samples, with a mean overestimation of $1.21 \pm 1.67 \mathrm{~kg}$ or $9.23 \pm 10.52 \%$. This might be a restriction in the potential use of this method as a detector of certain feedstuffs (e.g., to see whether grass silage or pasture was fed to produce a certain sample of milk). However, this inaccuracy seems to be limited to samples with observed values of 0 because the correlations over all samples are generally promising. In all 4 variants, the standard deviation for the correlation $\mathrm{R}_{\mathrm{val}}$ was always between 0.00 and 0.01 , indicating that the high correlations achieved for some feedstuffs and groups of feedstuffs are also very consistent over all 50 runs conducted.

Table 9 also shows the $95.0 \%$ and $99.0 \%$ quantiles of the estimated values of those samples, which had an observed value of 0 . In regard to the potential use of this method as a detector of a feedstuff in a ration, the values for the respective quantiles might be interpreted as thresholds for a certain probability that a feedstuff was actually part of the animal's ration. A similar procedure seems to be applied by researchers at the Dutch 
Table 8. Comparison of correlation between predicted and observed values and ratio to performance deviation (RPD; SD/root mean squared error) in all 4 variants of the partial least squares procedure ${ }^{1}$

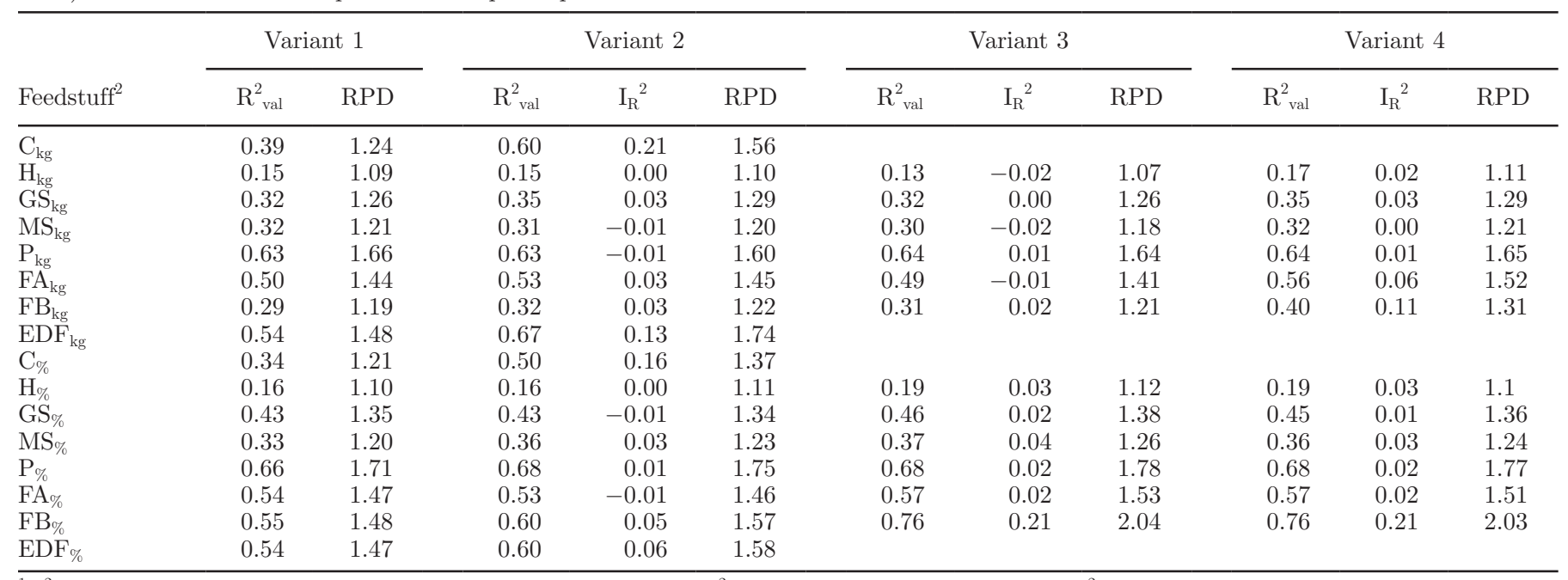

${ }^{1} \mathrm{R}_{\text {val }}^{2}=$ coefficient of determination in the validation data set; $\mathrm{I}_{\mathrm{R}}{ }^{2}=$ improvement relative to the $\mathrm{R}_{\text {val }}^{2}$ of variant 1 .

${ }^{2} \mathrm{C}=$ concentrate; $\mathrm{H}=$ hay; $\mathrm{GS}=$ grass silage; $\mathrm{MS}=$ maize silage; $\mathrm{P}=$ pasture; $\mathrm{FA}=$ forages $\mathrm{A}$ (consisted of hay and grass silage); $\mathrm{FB}=$ forages $\mathrm{B}$ (consisted of hay, grass silage, and pasture); $\mathrm{EDF}=$ energy-dense feedstuffs (specifically concentrate and maize silage). Subscript $\mathrm{kg}=$ kilograms of DMI in feedstuffs; subscript \% = percentages of feedstuffs in the total feed ration.

private institute Qlip, who have developed a "fresh grazed grass indicator." This method aims to determine whether a cow has been fed fresh herbage by analyzing the MIR spectra of milk samples. In this method, MIR spectra are used to estimate milk composition, which in turn is supposed to be an indicator of fresh herbage in the animal's feed ration (Qlip, 2016). The RMSE offers a different angle, substantiating our interpretation that individual estimations can be rather inaccurate even when $\mathrm{R}_{\text {val }}^{2}$ is promising. The confidence interval at $P$ $<0.05$ is \pm RMSE $\times 1.96$. For example, the RMSE for $\mathrm{C}_{\mathrm{kg}}$ in variant 1 is $2.41 \mathrm{~kg}$, meaning that the confidence interval for any estimate would be $\pm 4.73 \mathrm{~kg}$, which is large considering the average observed concentrate intake of $3.31 \pm 2.99 \mathrm{~kg}$.

The estimations from 1 run of the PLS procedure for $\mathrm{FB}_{\mathrm{kg}}$ are visualized in Figure 1. The $\mathrm{R}_{\text {val }}^{2}$, bias, and slope for this run were similar to the corresponding

Table 9. Mean estimated value for an individual feedstuff or a group of feedstuffs when the observed value was 0 , or thresholds for a certain probability that a feedstuff was actually part of the animal's ration

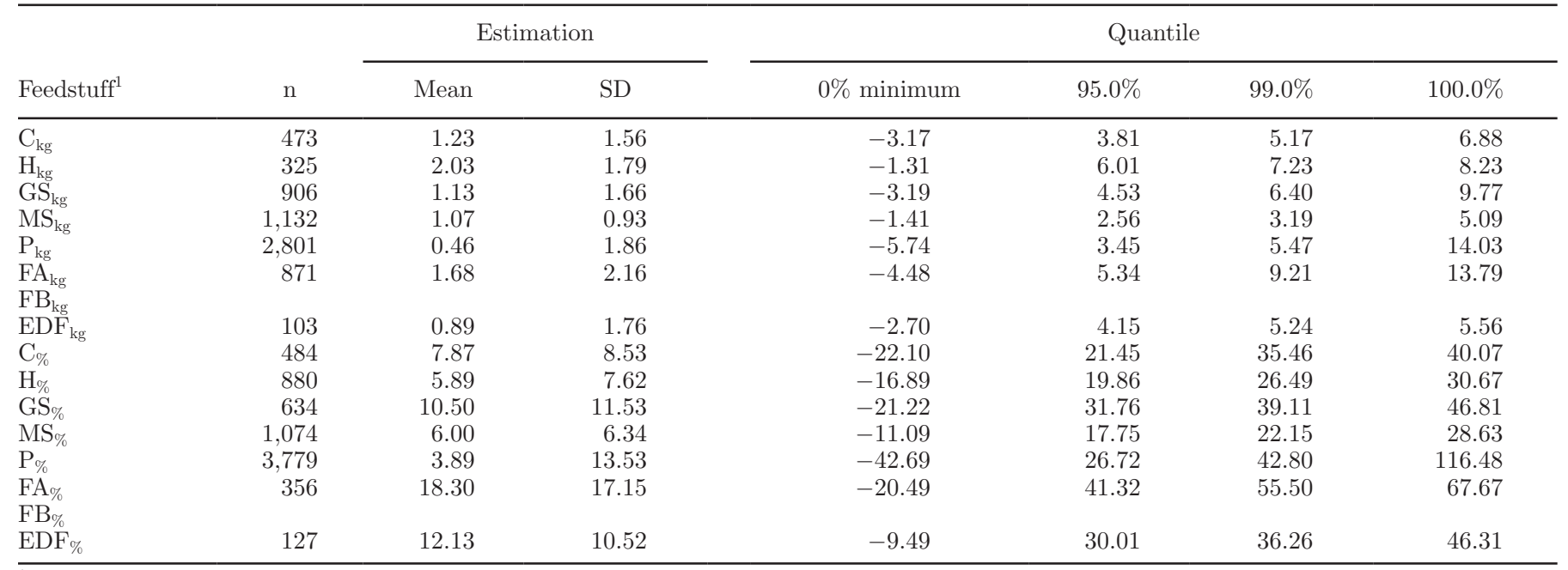

${ }^{1} \mathrm{C}=$ concentrate; $\mathrm{H}=$ hay; $\mathrm{GS}=$ grass silage; $\mathrm{MS}=$ maize silage; $\mathrm{P}=$ pasture; $\mathrm{FA}=$ forages $\mathrm{A}$ (consisted of hay and grass silage); $\mathrm{FB}=$ forages $\mathrm{B}$ (consisted of hay, grass silage, and pasture); $\mathrm{EDF}=$ energy-dense feedstuffs (specifically concentrate and maize silage). Subscript kg $=$ kilograms of DMI in feedstuffs; subscript $\%=$ percentages of feedstuffs in the total feed ration. 


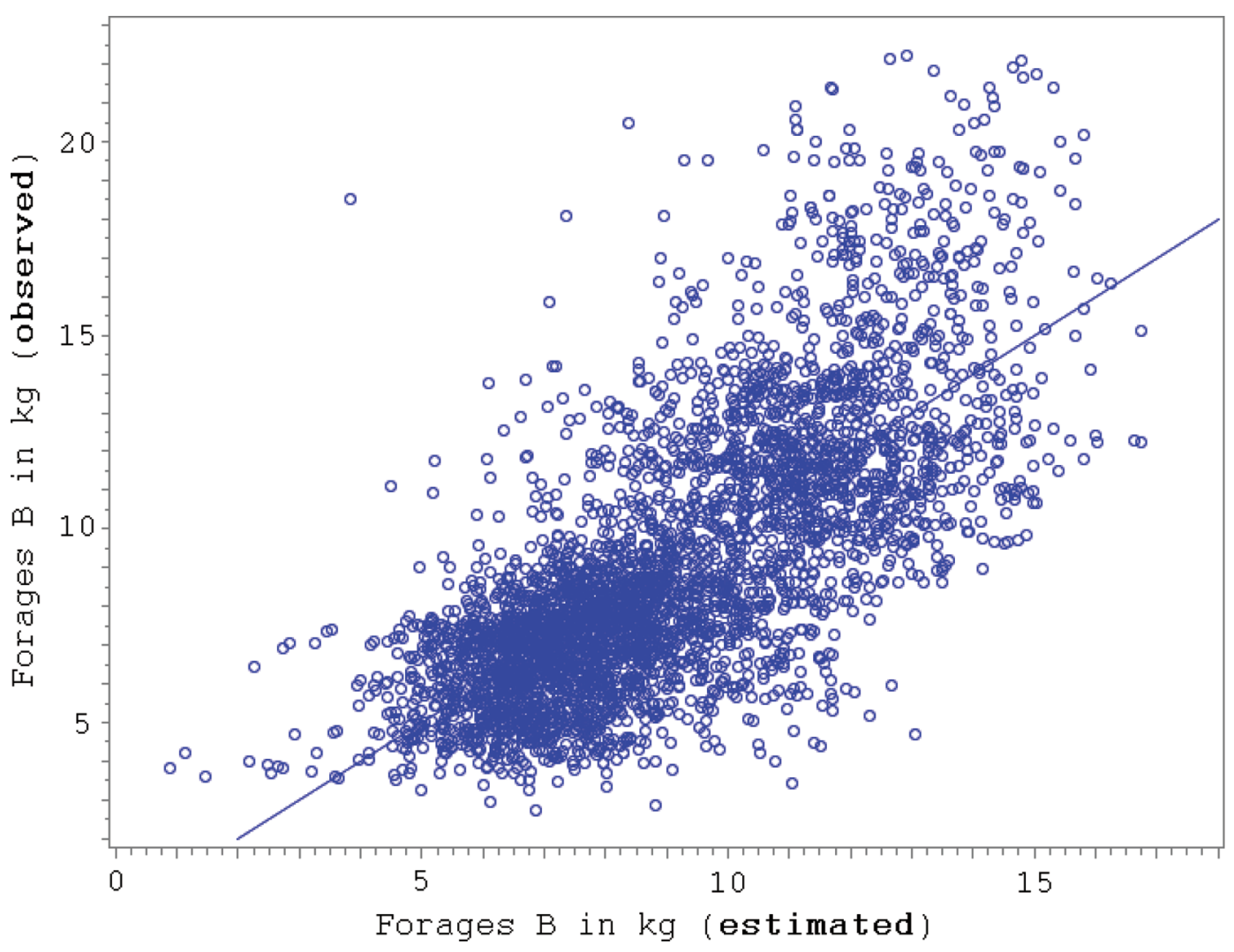

Figure 1. Amount of the feedstuff group forages B (hay, grass silage, and pasture) in ration (in $\mathrm{kg}$ ) as observed ( $x$-axis) and predicted ( $y$ axis). Results from 1 run with $R_{\mathrm{val}}=0.71, \mathrm{RMSE}_{\mathrm{val}}=2.38$, slope $=0.93$, and bias $=0.00$. $\mathrm{R}_{\mathrm{val}}=$ correlation between observed and estimated values in the validation data set; $\mathrm{RMSE}_{\mathrm{val}}=$ root mean squared error of estimations in the validation data set. Color version available online.

values averaged over 50 runs. Figure 1 shows the strong dispersion of the cloud of estimations across the graph linking observed and predicted values, indicating that although average estimates might be accurate, individual estimates may be far off at times.

Figure 2 was prepared in the same manner as Figure 1 but illustrates the dispersion of the cloud across the graph linking observed and predicted values for the individual feedstuff $\mathrm{H}_{\mathrm{kg}}$. The dispersion of estimates was extremely strong, especially when the respective feedstuffs did not occur in the animal's diet. However, when the feedstuff was part of the ration the accuracy of estimations seemed to be significantly higher.

\section{CONCLUSIONS}

In this study we explored the options for creating a method to estimate the feed ration of dairy cows cheaply and accurately using MIR spectra from a standard milk recording procedure. The degree of accuracy was not the same for different feedstuffs, but estimates for all groups of feedstuffs and certain single feedstuffs such as pasture, maize silage, and concentrates were promising. Further research is needed to determine whether and how accuracy of estimation can be increased and how the results can be implemented in the development of a useful method that is applicable in the dairy industry. Although estimations for some categories are good on average, individual estimations can deviate strongly. Thus, studies examining MIR spectra of repeated samples of bulk milk of herds following alternative feed regimens and ration compositions are required.

\section{ACKNOWLEDGMENTS}

We thank the staff of the research farms of the Agricultural Research and Education Centre RaumbergGumpenstein (Austria) for their cooperation as well as their care and management of the experimental cows. We especially acknowledge the support of Rupert Pfister, Hannes Rohrer, Andrea Adelwöhrer, and Johann Häusler (The Agricultural Research and Education Centre Raumberg-Gumpenstein, Austria) in collection of the data. 


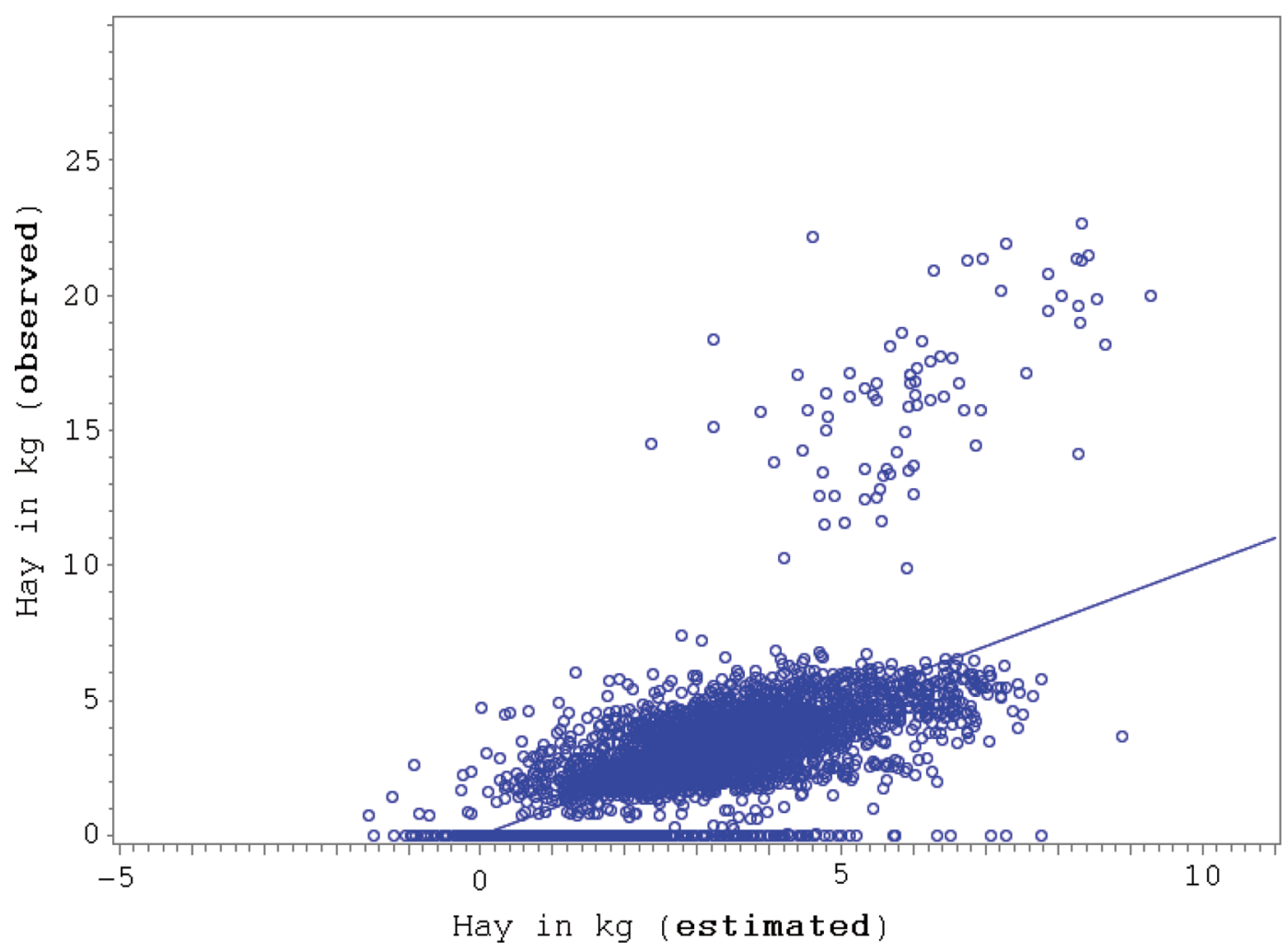

Figure 2. Percentage of hay in the ration as observed ( $x$-axis) and predicted ( $y$-axis). Results from 1 run with $\mathrm{R}_{\mathrm{val}}=0.60, \mathrm{RMSE}_{\mathrm{val}}=12.5$, slope $=0.92$, and bias $=0.00 . R_{\text {val }}=$ correlation between observed and estimated values in the validation data set; $R M S E_{\text {val }}=$ root mean squared error of estimations in the validation data set. Color version available online.

\section{REFERENCES}

Besle, J. M., D. Viala, B. Martin, P. Pradel, B. Meunier, J. L. Berdague, D. Fraisse, J. L. Lamaison, and J. B. Coulon. 2010. Ultraviolet-absorbing components in milk are related to forage polyphenols. J. Dairy Sci. 93:2846-2856.

Coppa, M., C. Chassaing, A. Ferlay, C. Agabriel, C. Laurent, G. Borreani, R. Barcarolo, T. Baars, D. Kusche, O. M. Harstad, J. Verbic, J. Golecky, C. Delavaud, Y. Chilliard, and B. Martin. 2015. Potential of milk fatty acid composition to predict diet composition and authenticate feeding systems and altitude origin of European bulk milk. J. Dairy Sci. 98:1539-1551.

De Marchi, M., V. Toffanin, M. Cassandro, and M. Penasa. 2014. Invited review: Mid-infrared spectroscopy as phenotyping tool for milk traits. J. Dairy Sci. 97:1171-1186.

de Roos, A. P., H. J. van den Bijgaart, J. Hørlyk, and G. de Jong. 2007. Screening for subclinical ketosis in dairy cattle by Fourier transform infrared spectrometry. J. Dairy Sci. 90:1761-1766.

Dehareng, F., C. Delfosse, E. Froidmont, H. Soyeurt, C. Martin, N. Gengler, A. Vanlierde, and P. Dardenne. 2012. Potential use of milk mid-infrared spectra to predict individual methane emission of dairy cows. Animal 6:1694-1701.

Ferrand-Calmels, M., I. Palhière, M. Brochard, O. Leray, J. M. Astruc, M. R. Aurel, S. Barbey, F. Bouvier, P. Brunschwig, H. Caillat, M. Douguet, F. Faucon-Lahalle, M. Gelé, G. Thomas, J. M. Trommenschlager, and H. Larroque. 2014. Prediction of fatty acid profiles in cow, ewe, and goat milk by mid-infrared spectrometry. J. Dairy Sci. 97:17-35.

Gesellschaft für Ernährungsphysiologie (GfE). 2001. Empfehlungen zur Energie- und Nährstoffversorgung der Milchkühe und Aufzuchtrinder. Ausschuss für Bedarfsnormen der Gesellschaft für Ernährungsphysiologie. DLG-Verlag, Frankfurt, Germany.
Gottardo, P., M. De Marchi, M. Cassandro, and M. Penasa. 2015. Technical note: Improving the accuracy of mid-infrared prediction models by selecting the most informative wavelengths. J. Dairy Sci. 98:4168-4173.

Grelet, C., C. Bastin, M. Gelè, J.-B. Davière, M. Johan, A. Werner, R. Reding, J. A. Fernandez Pierna, F. G. Colinet, P. Dardenne, N. Gengler, H. Soyeurt, and F. Dehareng. 2016. Development of Fourier transform mid-infrared calibrations to predict acetone, beta-hydroxybutyrate, and citrate contents in bovine milk through a European dairy network. J. Dairy Sci. 99:4816-4825.

Horn, M., A. Steinwidder, J. Gasteiner, L. Podstatzky, A. Haiger, and W. Zollitsch. 2013. Suitability of different dairy cow types for an Alpine organic and low-input milk production system. Livest. Sci. 153:135-146.

Horn, M., A. Steinwidder, W. Starz, R. Pfister, and W. Zollitsch. 2014. Interactions between calving season and cattle breed in a seasonal Alpine organic and low-input dairy system. Livest. Sci. 160:141-150.

Karoui, R., A. M. Mouazen, E. Dufour, L. Pillonel, E. Schaller, J. De Baerdemaeker, and J. O. Bosset. 2006. Chemical characterisation of European Emmental cheeses by near infrared spectroscopy using chemometric tools. Int. Dairy J. 16:1211-1217.

Larsen, T., L. Alstrup, and M. R. Weisbjerg. 2016. Minor milk constituents are affected by protein concentration and forage digestibility in the feed ration. J. Dairy Res. 83:12-19.

Maurice-Van Eijndhoven, M. H. T., H. Soyeurt, F. Dehareng, and M. P. L. Calus. 2013. Validation of fatty acid predictions in milk using mid-infrared spectrometry across cattle breeds. Animal 7:348-354.

McParland, S., G. Banos, B. McCarthy, E. Lewis, M. P. Coffey, B. O'Neill, M. O'Donovan, E. Wall, and D. P. Berry. 2012. Validation of mid-infrared spectrometry in milk for predicting body energy status in Holstein-Friesian cows. J. Dairy Sci. 95:7225-7235. 
McParland, S., G. Banos, E. Wall, M. P. Coffey, H. Soyeurt, R. F. Veerkamp, and D. P. Berry. 2011. The use of mid-infrared spectrometry to predict body energy status of Holstein cows. J. Dairy Sci. 94:3651-3661.

McParland, S., E. Kennedy, E. Lewis, S. G. Moore, B. McCarthy, M. O'Donovan, and D. P. Berry. 2015. Genetic parameters of dairy cow energy intake and body energy status predicted using midinfrared spectrometry of milk. J. Dairy Sci. 98:1310-1320.

Nozière, P., P. Grolier, D. Durand, A. Ferlay, P. Pradel, and B. Martin. 2006. Variations in carotenoids, fat-soluble micronutrients, and color in cows' plasma and milk following changes in forage and feeding level. J. Dairy Sci. 89:2634-2648.

Prinz, M. 2015. Einfluss einer kurzfristigen Energieunterversorgung auf Milchleistung, physiologische Parameter und das Mid-InfrarotSpektrum der Milch von Kühen im ersten Laktationsdrittel. University of Natural Resources and Life Sciences Vienna, Austria.

Qlip. 2016. The fresh grazed grass indicator. Accessed May 29, 2016. http://www.qlip.nl/en/actual/news/428-the-fresh-grazed-grassindicator.

Rinnan, A., F. van den Berg, and S. B. Engelsen. 2009. Review of the most common pre-processing techniques for near-infrared spectra. Trends Anal. Chem. 28:1201-1222.

Slots, T., G. Butler, C. Leifert, T. Kristensen, L. H. Skibsted, and J. H. Nielsen. 2009. Potentials to differentiate milk composition by different feeding strategies. J. Dairy Sci. 92:2057-2066.

Soyeurt, H., D. Bruwier, J.-M. Romnee, N. Gengler, C. Bertozzi, D. Veselko, and P. Dardenne. 2009. Potential estimation of major mineral contents in cow milk using mid-infrared spectrometry. J. Dairy Sci. 92:2444-2454.

Soyeurt, H., F. G. Colinet, V. M.-R. Arnould, P. Dardenne, C. Bertozzi, R. Renaville, D. Portetelle, and N. Gengler. 2007. Genetic variability of lactoferrin content estimated by mid-infrared spectrometry in bovine milk. J. Dairy Sci. 90:4443-4450.

Soyeurt, H., P. Dardenne, F. Dehareng, G. Lognay, D. Veselko, M. Marlier, C. Bertozzi, P. Mayeres, and N. Gengler. 2006. Estimating fatty acid content in cow milk using mid-infrared spectrometry. J. Dairy Sci. 89:3690-3695.

Soyeurt, H., F. Dehareng, N. Gengler, S. McParland, E. Wall, D. P. Berry, M. Coffey, and P. Dardenne. 2011. Mid-infrared prediction of bovine milk fatty acids across multiple breeds, production systems, and countries. J. Dairy Sci. 94:1657-1667.

Starz, W., A. Steinwidder, R. Pfister, and H. Rohrer. 2010. Continuous grazing in comparison to cutting management on an organic meadow in the eastern Alps. Pages 1009-1011 in Proc. 23rd General Meeting of the European Grassland Federation, Kiel, Germany. Organising Committee of the 23th General Meeting of the European Grassland Federation and Arbeitsgemeinschaft Grünland und Futterbau der Gesellschaft für Pflanzenbauwissenschaften, Universität Göttingen, Germany.

Stergiadis, S., C. Leifert, C. J. Seal, M. D. Eyre, M. K. Larsen, T. Slots, J. H. Nielsen, and G. Butler. 2015. A 2-year study on milk quality from three pasture-based dairy systems of contrasting production intensities in Wales. J. Agric. Sci. 153:708-731.

Sutton, J. 1989. Altering milk composition by feeding. J. Dairy Sci. $72: 2801-2814$

Valenti, B., B. Martin, D. Andueza, C. Leroux, C. Labonne, F. Lahalle, H. Larroque, P. Brunschwige, C. Lecomte, M. Brochard, and A. Ferlay. 2013. Infrared spectroscopic methods for the discrimination of cows' milk according to the feeding system, cow breed and altitude of the dairy farm. Int. Dairy J. 32:26-32.

van Gastelen, S., and J. Dijkstra. 2016. Prediction of methane emission from lactating dairy cows using milk fatty acids and midinfrared spectroscopy. J. Sci. Food Agric. 96:3963-3968.

van Knegsel, A. T. M., S. G. A. van der Drift, M. Horneman, A. P. W. de Roos, B. Kemp, and E. A. M. Graat. 2010. Short communication: Ketone body concentration in milk determined by Fourier transform infrared spectroscopy: Value for the detection of hyperketonemia in dairy cows. J. Dairy Sci. 93:3065-3069.

Van Soest, P. J., J. B. Robertson, and B. A. Lewis. 1991. Methods for dietary fiber, neutral detergent fiber and nonstarch polysaccharides in relation to animal nutrition. J. Dairy Sci. 74:3583-3597.

Vanlierde, A., M. L. Vanrobays, N. Gengler, P. Dardenne, H. Soyeurt, S. McParland, E. Lewis, M. H. Deighton, M. Mathot, and F. Dehareng. 2016. Milk mid-infrared spectra enable prediction of lactation-stage-dependent methane emissions of dairy cattle within routine population-scale milk recording schemes. Anim. Prod. Sci. 56:258-264.

VDLUFA (Association of German Agricultural Analytic and Research Institutes). 2007. Book of Methods. Vol. III-The Chemical Analysis of Feedstuffs [in German]. VDLUFA-Verlag, Darmstadt, Germany.

White, S. L., J. A. Bertrand, M. R. Wade, S. P. Washburn, J. T. Green, and T. C. Jenkins. 2001. Comparison of fatty acid content of milk from Jersey and Holstein cows consuming pasture or a total mixed ration. J. Dairy Sci. 84:2295-2301. 